\title{
Functional properties of fermented soymilk by Lactobacillus fermentum BM-325
}

\author{
Batmunkh Myagmardorj ${ }^{1,2}$, Munkh-Erdene Purev ${ }^{2}$, Batjargal Batdorj $^{\star}$ \\ ${ }^{1}$ Institute of Chemistry and Chemical Technology, Mongolian Academy of Sciences, MAS $4^{\text {th }}$ building, Peace Avenue, \\ Bayanzurkh district, Ulaanbaatar 13330, Mongolia
}

${ }^{2}$ School of Arts and Sciences, National University of Mongolia, Ulaanbaatar 14200, Mongolia

*Corresponding author: batjargal@num.edu.mn; ORCID ID:0000-0001-5704-0087

Received: 18 October 2018; revised: 28 January 2019; accepted: 29 January 2019

\begin{abstract}
Soy products have attracted much attention recently as carriers for probiotics. Fermentation of soymilk with lactic acid bacteria (LAB) was found to improve the nutritional and bioactivity values of consumed foods. The aim of this study was to evaluate functional properties of fermented soymilk with probiotic LAB strain Lactobacillus fermentum BM-325, based on their growth behavior, enzymes and antioxidant activities. Growth behavior such as viable cell number, $\mathrm{pH}$, total acidity and enzyme activities were determined during fermentation period. Maximum number of viable cell was Log $\mathrm{LFU}_{10} \mathrm{CFl}{ }^{-1}$ 12.6 \pm 0.9 , maximum $\beta$-glucosidase activity was $78.9 \pm 3.9 \mathrm{U} \cdot \mathrm{mg}^{-1}$ and maximum $\alpha$-galactosidase activity was $97.7 \pm 4.8$ $\mathrm{U} \cdot \mathrm{mg}^{-1}$, as well as antioxidant activity was $\mathrm{IC}_{50} 0.04 \pm 0.002 \mathrm{mg} \cdot \mathrm{mL}^{-1}$. Angiotensin converting enzyme inhibitory (ACEI) activity was determined in fermented soymilk and in partially purified peptide fraction. The ACEI activity was reached $60 \%$ after $20 \mathrm{~h}$ fermentation in soymilk. Our results suggested that fermentation of Lactobacillus fermentum BM-325 in soymilk for $4 \mathrm{~h}$ could be used to increase bioactivity of soymilk and suitable for the development of functional food.
\end{abstract}

Keywords: soymilk, Lactobacillus fermentum, $\beta$-glucosidase, $\alpha$-galactosidase, antioxidant activity, ACEI activity

\section{INTRODUCTION}

Functional foods can be defined as dietary items that, besides providing nutrients and energy, beneficially modulate one or more targeted functions in the body, by enhancing a certain physiological response and/ or by reducing the risk of disease. They are bearing dietary fibers, prebiotics, probiotics, and synbiotics are linked to various health benefits [1]. A growing public awareness of diet related health issues and mounting evidence regarding health benefits of probiotics have increased consumers demand for food containing probiotic organisms. Probiotics are defined by the World Health Organization (WHO) as "live microorganisms, which when administrated in adequate amounts confer a health benefit on the host" [2].

Soybean and soy-based foods are a rich and inexpensive source of nutrition for lactose intolerant individuals, vegetarians. They contain high-quality proteins and isoflavones, which have several useful biological properties including anti-tumor activity, improvement in menopausal syndromes, and a reduction in the risk of atherosclerosis [3]. Isoflavones in soybeans and nonfermented soy foods typically exist in their glucoside form, and rarely in the aglycone form. Several studies indicate that increasing the bioavailability of glucosides requires hydrolysis of $\beta$-glucosidase from intestinal probiotics. It could be that fermentation of soymilk using $\beta$-glucosidase-producing lactic acid bacteria $(\mathrm{LAB})$ may break the glucoside bond and it results in more active aglycone compounds and therefore increase antioxidant activity [4]. Moreover, nondigestible oligosaccharides (NDO) in soybeans are not eliminated by any processing but specific enzyme ( $\alpha$-galactosidase) or an organism that possesses high $\alpha$-galactosidase activity. Some researchers have reported the reduction of NDO during fermentation of soymilk using following bacteria: Lactobacillus cellobiosis, L. plantarum, L. fermentum, L. pentosaceus etc [5]. In addition, biologically active peptides are generated during dairy fermentation by proteolytic 
enzymes produced by various $L A B$. These biologically active peptides include hypotensive peptides, opioid peptides and mineral binding, immunomodulatory, antibacterial, and antithrombotic peptides. Inhibition of angiotensin I-converting enzyme (ACE) mainly results in an overall hypotensive effect. Angiotensin I-converting enzyme (ACE, EC 3.4.15.1) is an important enzyme of the renin-angiotensin system, a major regulator of blood pressure in mammals [6].

As stated, the use of LAB on soymilk fermentation is very important governing factor to produce highly functional foods. Therefore, we investigated the functional properties of soymilk fermentation without any supplements. The objective of this study was to determine functional properties of fermented soymilk.

\section{EXPERIMENTAL}

Soybean sample: Non-GMO certified soybeans were obtained from Exhibition of Agricultural products - 2016 in Ulaanbaatar, Mongolia.

Bacterial culture: The starter LAB culture BM-325 was isolated from Mongolian traditional koumiss (2015) Bulgan province and characterized its probiotic properties in the laboratory of Biochemistry, National University of Mongolia. The stock culture was kept in $50 \%$ glycerol and stored at $-20^{\circ} \mathrm{C}$.

Identification of LAB: The genomic DNA was used as a template for PCR amplification of a segment of its 16S rRNA gene. The two $L$. fermentum specific primers used were, namely Lfermentum Forward: GCACCTGATTGATTTTGGTCG, Lfermentum Reverse: GTCCATTGTGGAAGATTCCC. PCR reaction mixture contained $2 \mu \mathrm{l}$ template DNA, $10 \mu \mathrm{l} 5 \mathrm{x}$ buffer, $8 \mu \mathrm{l}$ dNTP $(1.25 \mathrm{mM}), 0.3 \mu \mathrm{l}$ primer Lfermentum Forward $\left(50 \mathrm{pmol} \cdot \mu^{-1}\right), 0.3 \mu \mathrm{l}$ primer Lfermentum

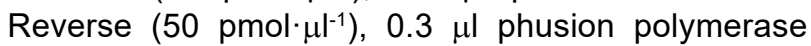
and $29.1 \mu \mathrm{l}$ water. PCR amplifying procedure was as follows: $5 \mathrm{~min}$ at $95^{\circ} \mathrm{C}, 25$ cycles of $45 \mathrm{sec}$ at $94^{\circ} \mathrm{C}, 30$ second at $62.5^{\circ} \mathrm{C}, 60 \mathrm{sec}$ at $72^{\circ} \mathrm{C}$ and then $10 \mathrm{~min}$ at $72^{\circ} \mathrm{C}$. it was carried out on the automatic thermal cycler. The sequencing of PCR products was performed by Big Dye terminator v3.1. The nucleotide sequence of the $16 S$ rRNA gene of strain was analyzed and aligned by the BLAST program on the NCBI website (http://www. ncbi.nlm.nih.gov/).

Soymilk (SM) preparation: Briefly, $100 \mathrm{~g}$ soybeans were soaked in the distilled water at 1:3 ratio $(\mathrm{w} / \mathrm{v})$ for $16 \mathrm{~h}$ at room temperature. Subsequently, all soaked beans in $800 \mathrm{~mL}$ of distilled water was ground in a hand blender (HR1361, Philips) at the maximum speed for $2 \mathrm{~min}$. The final volume of the blended soy bean was 10 times higher than dry soybean weight. Then, it was boiled for 2 minutes and filtered through a cheesecloth and obtained a milky-looking filtrate, which is known as soybean milk.

Fermentation: Stock $\mathrm{LAB}$ culture was thawed, inoculated $(1 \%, v / v)$ in MRS and incubated at $37^{\circ} \mathrm{C}$ overnight. Then the culture was transferred $(3 \%, v / v)$ to sterile soymilk and incubated at $37^{\circ} \mathrm{C}$ for $16 \mathrm{~h}$ for preparation of laboratory culture. Finally, the lab culture with concentration of $\log _{10} 6 \mathrm{CFU} \cdot \mathrm{mL}^{-1}$ was inoculated to soymilk for the main fermentation, which was carried out at $37^{\circ} \mathrm{C}$ for $20 \mathrm{~h}$.

Bacterial growth, acidification, and $p H$ determination: During the fermentation, bacterial growth was determined by plating decimal Ringer water dilutions $\left(10^{4}-10^{8}\right)$ of the fermented samples (each batch were taken at 0-6 and $20 \mathrm{~h}$ ) in triplicate into appropriate medium for each culture. The $\mathrm{pH}$ value of the fermented soymilk was measured with a $\mathrm{pH}$ meter (PB-10, Sartorius). An acidity was titrated with $0.1 \mathrm{~N} \mathrm{NaOH}$ in the presence of phenolphthalein as an indicator.

Preparation of extracellular extracts: The cells were harvested by centrifugation at $4000 \times \mathrm{g}\left(4^{\circ} \mathrm{C}\right)$ for 30 min every hour for 6 hours fermentation and at 20 hours. The supernatant was designated as the cell-free extracellular enzymatic extract (EE).

Assay of $\alpha$-galactosidase and $\beta$-glucosidase: EE were assayed for both enzyme activities according to the method of Scalabrini et al [7]. Briefly, $60 \mu \mathrm{L}$ of EE was mixed with $120 \mu \mathrm{L}$ of $5 \mathrm{mM}$ specific substrates PNPG ( $p$-nitrophenyl- $\alpha$-D-galactopyranoside, $p$-nitrophenyl- $\beta$ D-glucopyranoside) (Sigma-Aldrich) respectively and incubated at $37^{\circ} \mathrm{C}$ for $30 \mathrm{~min}$. The reaction was stopped by addition of $120 \mu \mathrm{L}$ of cold $0.2 \mathrm{M}$ sodium carbonate. One unit of enzyme activity was defined as the amount of enzyme released $1 \mu \mathrm{mol}$ of $p$-nitrophenol from pNPG per milliliter per min under the assay conditions. The specific activity was expressed as units $(U)$ both enzyme activities per milligram of protein.

Antioxidant capacity using $\mathrm{ABTS}^{+}$method: The antioxidant activity was determined using $\mathrm{ABTS}^{+}$ (2,2-azino-bis (3-ethyl-benzothiazoline-6-sulfonic acid)) (Sigma-Aldrich) radical cation method. $\mathrm{ABTS}^{+}$was produced by reacting solution with $2.45 \mathrm{mM}$ potassium persulfate (final concentration) and allowing the mixture to stand at room temperature for $16 \mathrm{~h}$ before use. This radical was dissolved in water $(7 \mathrm{mM})$. Before the analysis, $\mathrm{ABTS}^{+}$solution was diluted with ethanol, to an absorbance of $0.700-0.020$ at $734 \mathrm{~nm}$. After addition of $10 \mu \mathrm{L}$ of each sample in $1 \mathrm{~mL}$ of $\mathrm{ABTS}^{+}$solution, the absorbance was measured in $6 \mathrm{~min}$. The results were determined using standard curve and expressed as $\mathrm{IC}_{50}\left(\mathrm{mg} \cdot \mathrm{mL}^{-1}\right)$, which is the minimum concentration to inhibit $50 \%$ of the $\mathrm{ABTS}^{+}$radical cation.

Proteolytic activity in fermented soymilk: The degree of proteolysis during fermentation of soymilk was determined by measuring the release of free $\mathrm{NH}_{3}$ groups following the o-phthaldialdehyde (OPA) (SigmaAldrich) method. $100 \mu \mathrm{l}$ of fermented milk sample was added to $750 \mu \mathrm{l}$ of OPA reagent and after $2 \mathrm{~min}$ at room temperature, absorbance of the solution was measured by a spectrophotometer (UVmini-1240, Shimadzu) at $340 \mathrm{~nm}$. The proteolytic activity of these bacterial cultures was expressed as the absorbance 
of free amino groups measured at $340 \mathrm{~nm}$. A relative degree of proteolysis was determined as the difference between proteolytic activity in fermented milk to that of unfermented milk [8].

Determination of protein concentration: During the fermentation, protein concentration was determined by use of a Bradford assay according to the manufacturer protocol (Bio-Rad) [9].

Assay for ACE inhibitory activity: The ACE inhibitory activity was assayed by using the Lieberman method with some modification [10] For each assay, $65 \mathrm{ml}$ of a sample solution and $50 \mathrm{ml}$ of $12.5 \mathrm{mM}$ Hip-His-Leu (Sigma-Aldrich) as a substrate in a borate buffer $(\mathrm{pH}$ 8.3) containing $1 \mathrm{M} \mathrm{NaCl}$ were incubated with $10 \mathrm{ml}$ of $2 \mathrm{mU}$ ACE (Sigma-Aldrich) for $1 \mathrm{~h}$ at $37^{\circ} \mathrm{C}$. The reaction was stopped by adding $125 \mathrm{ml}$ of $0.5 \mathrm{M} \mathrm{HCL}$. The liberated hippuric acid was extracted with $750 \mathrm{ml}$ of ethyl acetate, and $200 \mathrm{ml}$ of the resulting extract was then evaporated to air-dry state with a dry block thermostat (Bio TDB-100, Biosan). The precipitate was dissolved in $1.2 \mathrm{ml}$ of $1 \mathrm{M} \mathrm{NaCl}$, and the absorbance at $228 \mathrm{~nm}$ was then measured. The extent of inhibition was calculated as follows:

$$
\text { ACE-inhibitory activity }(\%)=1-\left[\frac{C-D}{A-B}\right] \times 100
$$

A - absorbance in presence of ACE and the buffer only;

$B$ - absorbance in the presence of buffer only;

C - absorbance in the presence of ACE, ACE-inhibitory component and the buffer;

D - absorbance in the presence of ACE-inhibitory component and the buffer.

Purification of ACE inhibitory peptides: Most promising batch sample (soymilk whey) of the fermentation was fractionated by ultrafiltration membranes (Ultrafiltration cell model 8050 and Ultra centrifugal filter, Millipore, Amicon) having molecular cut-offs $50 \mathrm{kDa}$ and $3 \mathrm{kDa}$. Moreover, the permeate was fractionated using a Sephacryl S-100 (16/60, $120 \mathrm{~mL})$ previously equilibrated with sodium phosphate buffer (0.05 M, pH 7.0). Peptides were eluted at a flow rate of $0.5 \mathrm{~mL} \cdot \mathrm{min}^{-1}$, and elution peaks were monitored at $280 \mathrm{~nm}$. Fractions were collected at 4 min intervals. All elution experiments were conducted by Äkta prime FPLC system.

Statistical analysis: All values are represented in triplicate results. And mean averages, standard deviations were calculated.

\section{RESULTS AND DISCUSSION}

Identification: The starter culture strain BM-325 was initially isolated from "airag" sample in 2014 and stored in laboratory condition. It was characterized by using API $50 \mathrm{CHL}$ fermentation kit (data not shown). By $16 \mathrm{~S}$ rRNA gene sequence analysis, BM-325 was classified as Lactobacillus fermentum with 99\% identity. Previously, it was also isolated and characterized from "airag" [12].
L. fermentum is a LAB that has been isolated in a variety of milk and vegetable derived products [11]. In last few decades, intensive research dealing with fermentation of soymilk using Lactobacillus strains was carried out worldwide [13].

Growth patterns: Fermentation with $L A B$ also provides to improve the functional value of soymilk [14]. The growth of the L. fermentum BM-325 in SM is shown in Figure 1. The viable cell count reached values of between $\log _{10} 6.2$ and $9.4 \mathrm{CFU} \cdot \mathrm{ml}^{-1}$ after $6 \mathrm{~h}$ fermentation. After $4 \mathrm{~h}$ of incubation, viable cell count reached $\log _{10} 8.9 \mathrm{CFU} \cdot \mathrm{ml}^{-1}$. It indicates sufficient number of viable cells for the production of probiotic dairies [15]. The $\mathrm{pH}$ value decreased until 4.5 in the first $5 \mathrm{~h}$ of the fermentation. In case of lactobacilli, the drop in $\mathrm{pH}$ was more pronounced from 4 to $8 \mathrm{~h}$ [16]. General acidity was $148.7 \mathrm{~T}^{\circ}$ and viable cell counts was $\log _{10}$ 12.6 CFU $\cdot \mathrm{ml}^{-1}$ after $20 \mathrm{~h}$ of incubation. It represents that $10 \%$ of soymilk was sufficient source of medium for L.fermentum BM-325.

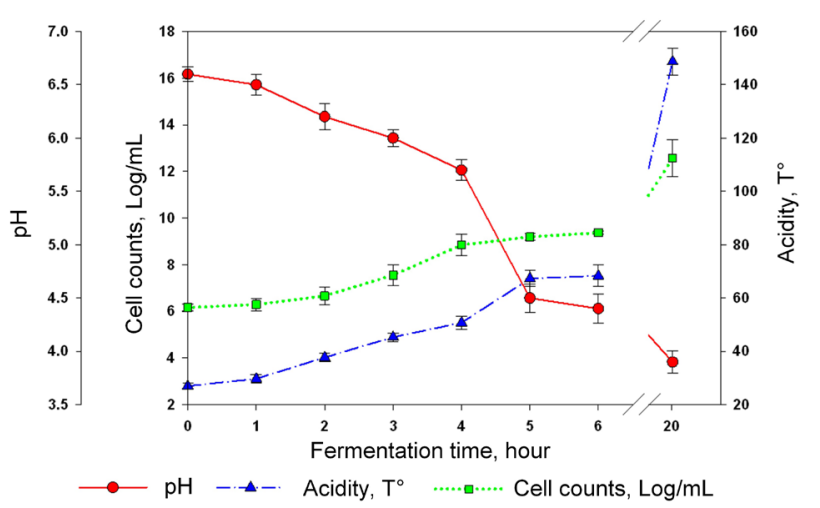

Fig. 1. Fermentation profile of Lactobacillus fermentum BM-325 in soy milk at $37^{\circ} \mathrm{C}$

Proteolytic properties in soymilk fermentation: LABs are characterized by their high demand for essential growth factors such as peptides and amino acids. However, milk does not contain sufficient free amino acids and peptides to allow growth of LAB. Therefore, these $L A B$ possess a complex system of proteinases and peptidases, which enable them to use milk protein as a source of amino acids and nitrogen. The proteolytic activities of $L A B$ including yogurt bacteria and probiotic bacteria have been studied extensively. The monitoring of hydrolysis in soymilk fermentation was determined by analyzing the amount of released primary amino groups and soluble protein content. The proteolytic activity of $L$. fermentum is usually utilized in animal derived dairy products [17]. In our case, we have inoculated L. fermentum BM-325 into soymilk for fermentation. Soymilk was the most acceptable medium for L. fermentum BM-325, based on our previous medium screening study (data not shown). During fermentation, soymilk proteins were hydrolyzed by LAB proteolysis resulting in an enhanced 


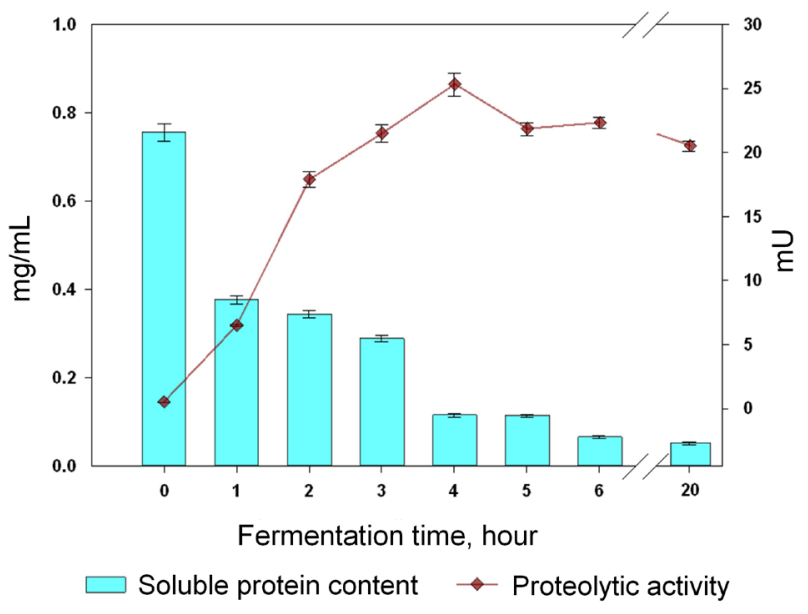

Fig. 2. Dynamics of soluble protein content and proteolytic activity during fermentation

amount of free amino groups and peptides (Figure 2). The most significant proteolysis occurred after $4 \mathrm{~h}$. The content of amino groups and peptides increased slightly $(\mathrm{P}<0.05)$ between $4 \mathrm{~h}$ to $20 \mathrm{~h}$ of fermentation. Proteolysis rate was stabilized between in 25.3 to 20.5 $\mathrm{U} \cdot \mathrm{ml}^{-1}$ and soluble protein content was between 0.12 to $0.05 \mathrm{mg} \cdot \mathrm{ml}^{-1}$ after $4 \mathrm{~h}$ of incubation. It shows us that our soymilk fermentation reached its highest proteolysis rate after $4 \mathrm{~h}$. The extent of proteolysis appeared to be time-dependent. Other studies have also reported proteolytic activities with $\mathrm{LAB}$ in soy-based products [18]. These results indicate that $L$. fermentum BM-325 strain showed proteolytic activity in soymilk (Figure 2). We assumed that the peptides in fermented soymilk may also contribute to its antioxidant activity.

Antioxidant activity, $\alpha$-galactosidase and $\beta$-glucosidase activity: Human consumption of soy products has been hampered by the presence of nondigestible oligosaccharides (NDO) (i.e. $\alpha$-galactosides such as raffinose and stachyose) in soybeans, which are not eliminated by any processing but hydrolytic digestion. The use of microbial $\alpha-\mathrm{Gal}$ is a promising solution for the degradation of these NDO in soy products. LAB such as Lactobacillus plantarum, $L$. fermentum, L. brevis, $L$. buchneri and $L$. reuteri are able to hydrolyze $\alpha$-galactosides into digestible carbohydrates during vegetable fermentations [19].

Isoflavones are present in soy foods mainly as glucosides. The glucoside isoflavones are very poorly absorbed in the small intestine as compared with their aglycones, because of their greater molecular weight and higher hydrophilicity of the glucosides. Human isoflavone bioavailability depends upon the relative ability of gut microflora to degrade these compounds. Therefore, bacteria with $\beta$-glucosidase activity are potentially important in the production of compounds with higher estrogenicity and better absorption, facilitating the bioavailability of isoflavones. There are many other LABs such as L. casei, L. acidophilus, L. reuteri, and
Bifidobacterium longum, B. animalis [20] which has $\beta$-glucosidase activity in soymilk fermentation during 24 h. However, there is no record of $\beta$-glucosidase activity in soymilk fermentation by $L$. fermentum.

Furthermore, fermentation of soymilk using $\beta$-glucosidase producing LAB may break the glucoside bond, results in more active aglycone compounds and therefore increases antioxidant activity [21].

We have determined $\alpha$-galactosidase, $\beta$-glucosidase activities of $L$. fermentum BM-325 on soymilk fermentation. And evaluated the antioxidant activities during 20 $\mathrm{h}$ fermentation. The development of antioxidant activity during fermentation was studied with ABTS assay. The antioxidant activity was increased in most of our cases and highest antioxidant activity was equal to $\mathrm{IC}_{50} 0.07$ $\mathrm{mg} \cdot \mathrm{ml}^{-1}$ reached after $3 \mathrm{~h}$ of fermentation. It showed us that antioxidant activity was about 10 times higher than the initial stage of fermentation. $\alpha$-galactosidase and $\beta$-glucosidase activity was measured by pNGP assay.

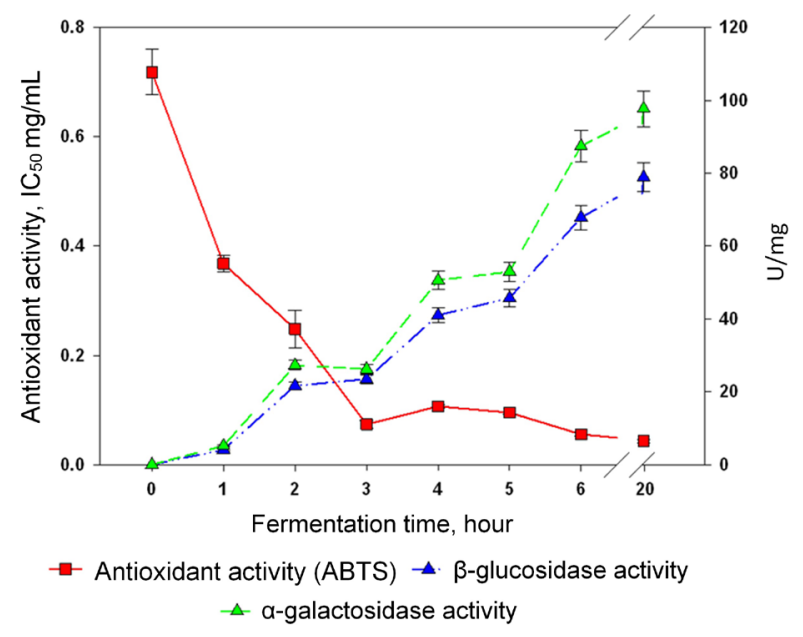

Fig. 3. $\alpha$-galactosidase, $\beta$-glucosidase, and antioxidant activity dynamics of fermented soymilk

Both enzyme activities were constantly increased to $67.8 \pm 4.2 \mathrm{U} \cdot \mathrm{mg}^{-1}(\alpha-\mathrm{Gal}), 87.4 \pm 3.3 \mathrm{U} \cdot \mathrm{mg}^{-1}(\beta-\mathrm{Glu})$ in $6 \mathrm{~h}$. Similar to our findings LeBlanc et al [5]. Also showed that the $\alpha$-galactosidase activity was constantly increased for first $6 \mathrm{~h}$. Our evaluation results of $\beta$-glucosidase relation to the experimental procedure during fermentation of soymilk results were similar to that of C. R. Rekha et al. [22]. L. fermentum BM-325 showed increased enzyme activity $\left(97.7 \pm 3.9 \mathrm{U} \cdot \mathrm{mg}^{-1}\right)$ at $20 \mathrm{~h}$ of fermentation.

Partial purification of soymilk whey: Over the last decade or so, the focus of soy research has shifted to the identification and characterization of bioactive peptides and their corresponding physiological functions. Numerous soy peptides with widespread beneficial physiological effects including lipid lowering (hypocholesterolemic, hypotriglyceridemic, anti- 
Table 1. ACE inhibitory efficiency ratio of partial peptide fraction obtained from of fermented soymilk whey

\begin{tabular}{lllll}
\hline & $\begin{array}{l}\text { Soluble protein } \\
\text { content, } \mathbf{m g} \cdot \mathbf{m l}^{-1}\end{array}$ & ACEl activity, \% & $\begin{array}{l}\text { ACEI activity per mg } \\
\text { of soluble protein, \% }\end{array}$ & $\begin{array}{l}\text { Increase in } \\
\text { specific activity }\end{array}$ \\
\hline Soy milk & $0.755 \pm 0.02$ & $6.6 \pm 0.9$ & $8.8 \pm 1.2$ & 1.0 \\
Whey of fermented soymilk $(20 \mathrm{~h})$ & $0.051 \pm 0.003$ & $19 \pm 0.3$ & $372.5 \pm 5.8$ & 42.3 \\
Peptide fraction $(<3 \mathrm{kDa})$ & $0.007 \pm 0.001$ & $60 \pm 1.1$ & $8571.4 \pm 157.2$ & 971.8 \\
\hline
\end{tabular}

obesity) to anti-diabetic, anti-cancer, hypotensive, anti-inflammatory, and antioxidant in a variety of experimental models. Those peptides commonly consist of 2 to 50 amino acids. These peptides are the product of protein hydrolysis during LAB fermentation [23]. To determine ACE-inhibitory activity of small peptides we have developed partial purification method as described materials and methods.

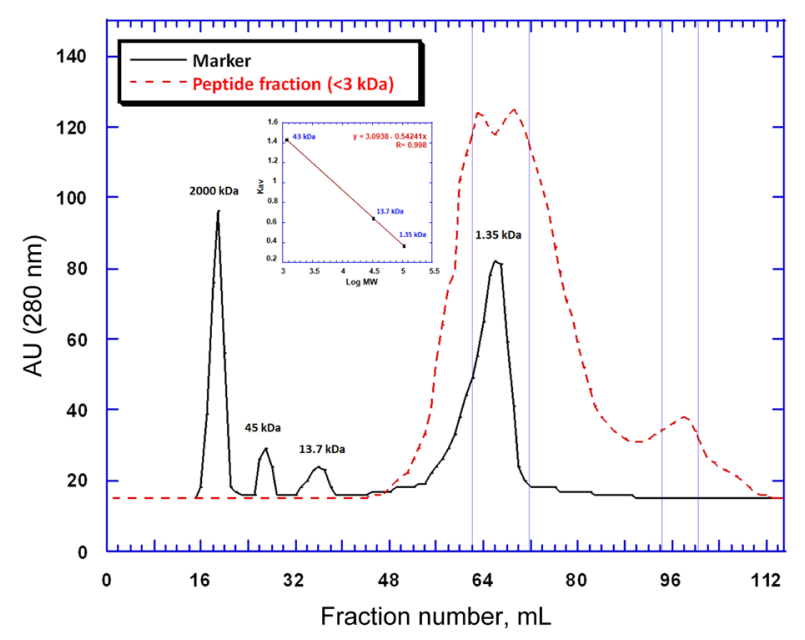

Fig. 4. Gel filtration chromatogram of partially purified peptide fraction using Sephacryl S-100 (16/60, $120 \mathrm{~mL}$ ) column

Peptide fraction was prepared as described in materials and methods. The peptides with molecular weight lesser than $3 \mathrm{kDA}$ were fractionated by cut-off membrane. The permeate was then purified by gel filtration chromatography on Sephacryl S-100 (16/60, $120 \mathrm{~mL}$ ) column. The purification step by gel filtration revealed the presence of two major peaks of peptides with molecular weight about $1300 \mathrm{Da}$ (Figure 4).

ACEI activity: Inhibition of ACE activity has been shown to effectively reduce blood pressure, and various ACE inhibitory peptides have been derived from many plant foods and animal muscle protein by enzymatic hydrolysis. ACE inhibitory peptides generated from porcine muscle by pepsin digestion, and from fermented soybean, natto, by protease digestion. In this study, we investigated the generation of ACE inhibitory peptides from processed soya milk to illustrate the health effects of consuming soybean products [24]. The ACE inhibitory effect of the peptide fraction was investigated using HHL substrate. The ACE inhibitory activity of the partially purified peptide fraction was compared to whole soymilk and fermented soymilk $(20 \mathrm{~h})$. The final specific activity of $\mathrm{ACEI}$, which represents the purification factor was about 971.8 times higher than that measured in the soymilk and 22.97 times higher than in the whey of fermented soymilk, respectively (Table 1 ).

It can be suggested that the development of soy yoghurt containing higher concentrations of released bioactive ACE inhibitors and viable probiotic may deliver health benefits of these functional compounds more efficiently [17].

\section{CONCLUSION}

Lactobacillus fermentum BM-325 isolated from Mongolian "airag" was able to grow on soymilk and could increase the functional properties of this product. Due to therapeutic level $\left(\log _{10} 8 \mathrm{CFU} \cdot \mathrm{ml}^{-1}\right)$ of viable cells, $4 \mathrm{~h}$ fermentation of $L$. fermentum BM-325 in soymilk would be enough to produce a probiotic beverage. At this time, the antioxidant activity was significantly increased, according to production of $\beta$-glucosidase activity. During the fermentation, the constant increasing of $\alpha$-galactosidase activity would be provided to allow non-digestible oligosaccharides degradation for its host. As a result of proteolytic activity, the peptides released during the fermentation showed ACE-inhibitory activity equal to $19 \pm 0.3 \%$ and this activity was increased 971.8 times after partial purification of peptides. Further studies should be focused on optimizing the sensory characteristics of this product.

\section{ACKNOWLEDGEMENTS}

We thank the Asia Research Center in Mongolia and the Korea Foundation for Advanced Studies, Korea for their support of the project "Probiotic properties of lactic acid bacteria isolated from plant and milk products". Part of this work was supported by Mongolian Foundation of Science and Technology (Research project 010/2015).

\section{REFERENCE}

1. Bultosa G. (2016) Functional Foods: Dietary Fibers, Prebiotics, Probiotics, and Synbiotics. Reference module in Food Science, Elsevier. DOI:10.1016/ B978-0-08-100596-5.00245-6

2. Guidelines for the evaluation of probiotics in food. (2002) Report of a joint FAO/WHO working group on drafting guidelines for the evaluation of 
probiotics in food. London Ontario, Canada, April 30 and May 1, 2002

3. Adetayo O., Rotimi Aluko E. (2005) Soybean foods and their benefits: Potential mechanisms of action. Nutrition Reviews, 63(8), 272-283. DOI:10.1111/j.1753-4887.2005.tb00141.x

4. Ebata J., Fukuda Y., Hirai K., \& Murata K. (1972) $\beta$-Glucosidase involved in the antioxidant formation in tempeh, fermented soybeans. Journal of the Agricultural Chemical Society of Japan, 46(7), 323-329. DOI:10.1271/nogeikagaku1924.46.323

5. LeBlanc J.G., Garro M.S., Silvestroni A., et al. (2004) Reduction of a-galactooligosaccharides in soyamilk by Lactobacillus fermentum CRL 722: in vitro and in vivo evaluation of fermented soyamilk. Journal of Applied Microbiology, 97(4), 876-881. DOI:10.1111/j.1365-2672.2004.02389.x

6. Korhonen H., Pihlanto A. (2003) Foodderived bioactive peptides - opportunities for designing future foods author(s). Current Pharmaceutical Design, 9(16), 1297-1308. DOI:10.2174/1381612033454892

7. Scalabrini P., Rossi M., Spettoli P., Matteuzzi D. (1998) Characterization of Bifidobacterium strains for use in soymilk fermentation. International Journal of Food Microbiology, 39(3), 213-219. DOI:10.1016/S0168-1605(98)00005-1

8. Neilsen P.M., Petersen D., Dambmann C. (2001) Improved method for determining food protein degree of hydrolysis. J. Food Sci., 66(5), 642-646. DOl:10.1111/j.1365-2621.2001.tb04614.x

9. Bio-Rad laboratories. USA. Protein Assay manual (1994) http://www.bio-rad.com/webroot/web/pdf/ Isr/literature/LIT33.pdf

10. Megumi Kuba., Kumi Tanaka., Shinkichi Tawata., et al. (2003) Angiotensin l-converting enzyme Inhibitory peptides isolated from Tofuyo fermented soybean food. Bioscience, Biotechnology, and Biochemsitry, 67(6), 1278-1283. DOI:10.1271/ bbB.67.1278

11. Gardiner G.E., Miren L. Baroja., Christine Heinemann et al. (2002) Oral administration of the probiotic combination Lactobacillus rhamnosus GR-1 and L. fermentum RC-14 for human intestinal applications. International Day of Journal 12(2-3), 191-196. DOI:10.1016/S09586946(01)00138-8

12. Oyundelger G., Sumisa F., Batjargal B., Yoshida T. (2016) Isolation and identification of new lactic acid bacteria with potent biological activity and yeasts in Airag, a traditional Mongolian fermented beverage. Food Science and Technology research, 22(5), 575-582. DOI:10.3136/fstr.22.575

13. Kobayashi M., Shima T. and Fukuda M. (2018) Metabolite profile of lactic acid-fermented soymilk. Food and Nutrition Sciences, 9(11), 1327-1340. DOI:10.4236/fns.2018.911095
14. Telang A.M., Joshi V.S., Sutar N., Thorat B.N. (2010) Enhancement of biological properties of soymilk by fermentation. Food Biotechnology, 24(4), 375-387. DOI:10.1080/08905436.2010.524489

15. Vinderola G., Binetti A., Burns P., Reinheimer J. (2011) Cell viability and functionality of probiotic bacteria in dairy products. Frontiers in Mincorbiology, 2(70), 1-6. DOl:10.3389/fmicB.2011.00070

16. Marisa S. Garro, G.F. de Valdez., Guillermo Oliver, G.S. de Giori. (1998) Growth characteristics and fermentation products of Streptococcus salivarius subsp. thermophilus, Lactobacillus casei and L.fermentum in soymilk. European Food Research and Technology, 206(1), 72-75. DOl:10.1007I $\underline{\mathrm{s} 002170050217}$

17. Santiago Ruiz-Moyano, Alberto Martín, María José Benito. (2011) Application of Lactobacillus fermentum HL57 and Pediococcus acidilactici SP979 as potential probiotics in the manufacture of traditional Iberian dry-fermented sausages. Food Microbiology, 28(5) 839-847. DOI:10.1016/j. fm.2011.01.006.

18. Donkor O. N., Henriksson A., Vasiljevic T., \& Shah N. P. (2005) Probiotic strains as starter cultures improve angiotensin-converting enzyme inhibitory activity in soy yoghurt. Journal of Food Science, 70(8), 375-381. DOl:10.1111/j.1365-2621.2005. tb11522.x

19. LeBlanc J.G., Garro M.S., Savoy de Giori G. (2004). Effect of $\mathrm{pH}$ on Lactobacillus fermentum growth, raffinose removal, $\alpha$-galactosidase activity and fermentation products. Applied microbial and cell physiology, 65(1), 119-123. DOI:10.1007/ s00253-003-1532-z

20. Otieno D.O., Ashton J.F., Nagendra Shah P. (2005) Stability of $\beta$-glucosidase activity produced by Bifidobacterium and Lactobacillus spp. in fermented soymilk during processing and storage. Journal of Food Science, 70(4), 236-241. DOI:10.1111/j.1365-2621.2005.tb07194.x

21. Jin Hur S., Yuan Lee S., Kim Y. (2014) Review: Effect of fermentation on the antioxidant activity in plant-based foods. Food Chemistry, 160(1), 346356. DOI:10.1016/j.foodchem.2014.03.112

22. Rekha C. R., Vijayalakshmi G. (2011) Isoflavone phytoestrogens in soymilk fermented with b-glucosidase producing probiotic lactic acid bacteria. International Journal of Food Sciences and Nutrition, 62(2), 111-120. DOI:10.3109/09637 486.2010.513680

23. Chatterjee C., Gleddie S., Xiao C. (2018) Review: Soybean bioactive peptides and their functional properties. setguuliin ner, 10(9), 1211, 1-16. DOI:10.3390/nu10091211

24. Tomatsu M., Shimakage A., Shinbo M. (2013) Novel angiotensin l-converting enzyme inhibitory peptides derived from soya milk. Food Chemistry, 136(2), 612-616. DOI:10.1016/j.foodchem.2012.08.080 